Previously reported missing, believed prisoner, now recorded killed in action, June, 1942.-Major H. M. R. Knight, R.A.M.C.

Prisoners of War.-Fl. Lieuts. D. A. Duthic, R.A.F., F. A. Forbes, C. B. I. Willey, F. R. Philps, A. F. Rutherford, R. R. McSwiney, L. C. Liddell, B. A. Stoll, H. J. Knox, R. G. Blackledge, J. Simpson, Kinmonth, R.A.F.V.R.

Correction.-Capts. (Temp. Majors) A. R. Clarke and W. C Gledhill and Capt. C. J. Cobbe, R.A.M.C., have been appointed M.B.E. (Military Division) in recognition of gallant and distinguished services in North Africa, and not O.B.E. as stated on Oct. 2, p. 439.

\section{Medical Notes in Parliament}

\section{Discussion before the White Paper}

Sir E. Graham-LitTle on Sept. 21 asked the Minister of Health whether he would explain in the forthcoming White Paper that the scope of the discussions he had been conducting with the Representative Committee was limited throughout by the stipulation that negotiations must be based on the acceptance of the decision taken by the Cabinet that a unified health service covering $100 \%$ of the population would be instituted and that its local administration would be in the hands of local authorities under the ultimate control of a Minister who would be responsible to Parliament. Mr. ERNEST Brown said that while he could not accept all the implications of the question, he agreed that the proposed White Paper reviewing this subject should make clear what preliminary steps (including discussions with the medical profession and others), had already been taken, and in what circumstances.

On Sept. 23 Mr. E. Brown told Mr. Robert Morgan that a number of other organizations had communicated with him on the subject of a National Health Service besides representatives of the medical profession, local authorities, and voluntary hospitals. He had made it clear, however, that when the White Paper was published he would be ready to receive from organizations and persons interested any representations which they wished to make in the light of their study of it. It would therefore be misleading to publish at the present time a list of those organizations who had communicated with him in advance, other than those whom he especially invited to enter into preliminary discussions.

\section{Nutrition in Newfoundland}

On Sept. $21 \mathrm{Mr}$. ATtLEe told Mr. Parker that he had recently approved proposals by the Commission of Government for launching a special nutrition campaign under the auspices of the Nutrition Council in Newfoundland. An expert dietitian was being engaged for the purpose, and certain other measures recommended by the council-e.g., for the importation of chemically reinforced flour--were also being introduced. It was hoped by these means to bring about a general improvement in dietary habits and to check at the outset the spreading of deficiency diseases, which, notwithstanding improved economic conditions, had lately tended to reappear.

\section{Inoculation against Typhus}

On Sept. 21 Sir JAMES Grigg, replying to Mr. Leach, said that all inoculations in the Army were voluntary. Every soldier now going to North Africa was, however, encouraged to receive this form of protection against typhus, and the majority of the troops in this theatre of operations had been inoculated. This type of inoculation had only been used for a short time and statistics were not yet available ; but experience indicated that it was valuable both in preventing the disease and in lessening its seriousness if it was contracted. Mr. LEACH asked to what experience Sir James Grigg was referring when he said it was justified. Sir JAMEs GRIGG: Experience in the pathological laboratories and in the few cases where typhus had appeared.

\section{Medical Care of Civil Deience Casualties}

Mr. ERNEST BRown informed Sir Ernest Graham-Little on Sept. 21 that casualties occurring in Civil Defence units were treated in the same way as casualties in the rest of the civilian population, at first-aid posts and hospitals included in the Emergency Medical Services, which were staffed by experienced surgeons equipped with the latest methods for the treatment of wounds bacterially infected or contaminated by mustard gas or similar gases. In making these arrangements his officers had consulted the Ministry's consultant advisers, the Medical Research Council, and the experts attached to the Ministry of Supply, and the numerous instructions issued to medical staffs of first-aid posts and hospitals were based on their advice. The Bunyan-Stannard envelope method of treatment was available for the use of those medical officers who wished to employ it.

\section{Registration of Older Women}

Opening a debate on Sept. 23 on man-power, Mr. ERNEST BEvIN said he had registered every man between 18 and 51 and all women between 18 and $47-10,000,000$ men and $10,000,000$ women. Of $33,000,000$ people between 14 and 64 , $22,750,000$ were in the Services, Civil Defence, or paid employment. In the country there were nearly $16,000,000$ males between 14 and 64 , over $15,000,000$ of whom were in the service of the country or in paid employment. Of $17,000.000$ women between the same ages, 7,750,000 were similarly engaged. Over $1,000,000$ other women were doing voluntary work, including nursing. Of single women between 18 and $40,91 \%$ were working. That left only $9 \%$ for sickness and various ailments. More than 1,000,000 men and women over 65 were in paid employment. He was unimpressed by the medical arguments against registration of women between the ages of 45 and 50 . When he had registered nurses and midwives up to 60 no one made a protest. He recognized that he would have to exercise great care with these women. None of them would be required to live away from home. There would be sympathetic treatment as regards their health and recognition of the difficulties of women in this age group. Sir HENRY MORRIS-JONES said that in women of these age categories inevitable disturbances occurred. The Government should not add anything to their difficulties which could not be proved to be necessary.

When the debate was resumed on Sept. 24, Mr. MCCoRQuoDALE said that pleas for women between 47 and 50 in respec of physical fitness would be treated sympathetically. $\mathrm{Mr}$ HOLDSWORTH asked if the appeal board would be able to go against a doctor's certificate. Mr. MCCORQUODALE replied that if the doctor's certificate was not clear or if other circumstances presented doubt it might be arranged for the woman to have independent examination, but that was not to be the normal practice. In the main in these age groups a medical certificate would be accepted without hesitation. All the women in these groups would be regarded as immobile; those up to 46 were regarded as mobile.

Dr. RUSSEll Thomas outlined the symptoms of the physiological and anatomical changes occurring in a woman between 45 and 51. The health fluctuated from week to week, and the question was not one of getting a medical certificate for two or three weeks. Proneness to accident and tendency to suicide were greater at that time of life than at any other. If a.woman of that age said she was not up to work she should have the benefit of the doubt.

\section{Shortage of Staff in Hospitals}

Mr. MESSER said that, notwithstanding applications to bring hospitals under the Essential Work Order, nothing had been done, and a grave situation was approaching. The Ministry of Health had brought out a scheme to attract people to have treatment for tuberculosis, but wards were closed because there was no staff. At Harefield Sanatorium the domestic staff were in the ratio of two for every 58 patients -70 below establishment. Hillingdon General Hospital was 40 under establishment in the domestic department. He hoped the Minister would not wait for the Hetherington Committee's report before acting. The Middlesex Hospital had required a typist familiar with medical terms. The Minister had confirmed a refusal by the National Service officer to allow such a typist from Essex Insurance Committee to take the job. Yet the local employment exchange provided another typist who knew nothing of medical terms. Special hospital man-power boards might overcome such difficulties. At Clare Hall Sanatorium the pharmacist received his calling-up papers. Arrangements were made for another to take the job, but the Central War Pharmacy Committee said that if the man did so his reservation would be cancelled.

Replying to the debate, Mr. BEviN said that he hoped to receive the Hetherington report in a few days. When he got it he would try to get the domestic side of the hospital service put right out of the registrations he had made and was now making. He knew that present difficulties reduced the efficiency of the trained nurses.

Notification of Venereal Disease.-Mr. ERnEst Brown, on Sept. 23 , told Lord Fermoy that he was not satisfied that the result of making venereal diseases notifiable would be to help in the control of the disease. He was keeping the mattr under consideration, but there had not yet been time to judge the effectiveness of the measures already taken.

T.T. and Accredited Milk.-The proportions of the total sales of milk in England and Wales which are of tuberculin-tested and accredited standards are $6 \%$ and $35 \%$ respectively. 